\title{
LA INFLUENCIA MUTUA DE ARQUEÓLOGOS Y ARQUITECTOS EN LA REPRESENTACIÓN GRÁFICA DE LA ARQUITECTURA HISTÓRICA DESDE MEDIADOS DEL SIGLO XVIII HASTA EL PRIMER TERCIO DEL XX*
}

\author{
THE MUTUAL INFLUENCE OF ARCHAEOLOGISTS \\ AND ARCHITECTS IN THE GRAPHIC REPRESENTATION \\ OF HISTORICAL ARCHITECTURE FROM THE MID-18TH CENTURY \\ TO THE FIRST THIRD OF THE 20TH CENTURY
}

\author{
Isabel OrDieres Díez**
}

Escuela Arquitectura Universidad de Alcalá de Henares (UAH)

\begin{abstract}
RESUMEN. Tomamos en este artículo el dibujo de la arquitectura histórica como punto del que partir a la hora de reflexionar sobre la mutua influencia entre arquitectos y arqueólogos. Se descubre una gran cantidad de matices cuando se analizan los abordajes desarrollados desde distintas disciplinas a la hora de representar los restos monumentales, tanto de la arquitectura antigua como medieval. Dependiendo de la formación de quienes lo hicieran, o lo dirigieran, dibujantes, ingenieros, arquitectos, historiadores, anticuarios o arqueólogos, trasmitieron visiones distintas, en ocasiones claramente opuestas e irreconciliables. En el dibujo se condensa siempre no solo la formación técnica, sino también los gustos y los intereses, y está cargado de intencionalidades sumamente iluminadoras.
\end{abstract}

PALABRAS CLAVE: Dibujo de monumentos, historiografía arquitectónica, arqueología clásica y medieval.

ABSTRACT. In this article we take the drawing of historical architecture as a starting point when reflecting on the mutual influence between architects and archaeologists. A great amount of nuances is discovered when analyzing the approaches developed from different disciplines when representing the monumental remains, both of ancient and medieval architecture. Depending on the training of those who did it, or directed it, draftsmen, engineers, architects, historians, antique dealers or archaeologists, transmitted different visions, sometimes clearly opposed and irreconcilable. Drawing always condenses not only technical training, but also tastes and interests and is loaded with extremely enlightening intentions.

KEYWORDS: Drawing of monuments, architectural historiography, classical and medieval archaeology.

* Este trabajo ha sido realizado dentro del proyecto: HAR2016-80271-P. Arqueología e Interdisciplinariedad: una investigación arqueológica-histórica sobre las relaciones interdisciplinares en la Historia de la Arqueología española (siglos xix y xx).

** Correspondencia a / Correspondence to: Isabel Ordieres Díez, Escuela Arquitectura Universidad de Alcalá de Henares (UAH) isabelrdrs@gmail.com - https://orcid.org/0000-0002-7627-3406.

Cómo citar / How to cite: Ordieres Díez, Isabel (2020), «La influencia mutua de arqueólogos y arquitectos en la representación gráfica de la arquitectura histórica desde mediados del siglo XVIII hasta el primer tercio del XX», Veleia, 37, 57-78. (https://doi.org/10.1387/veleia.20979).

Recibido: 1 julio 2019; aceptado: 29 octubre 2019.

ISSN 0213-2095 - elSSN 2444-3565 / (C) 2020 UPV/EHU 
Los caminos que se transitaron en el «redescubrimiento» de la arquitectura nacional española siguieron un mismo patrón: primero se generó el interés por una determinada época, que respondió a motivaciones en gran medida ideológicas y de búsqueda de respuestas para la renovación estética del momento. Posteriormente, se sintió la necesidad de "recuperar», de actuar materialmente sobre lo descubierto, ya fuese para restaurar los edificios o para hacer prospecciones arqueológicas, y ahí empezaron a divergir las distintas posturas disciplinares. A través de los dibujos monumentales podemos comprobar cómo fue cambiando la aproximación a la arquitectura del pasado y cómo estas divergencias contribuyeron a ir perfilando metodologías y a definir las propias disciplinas, en concreto, la arqueológica. Mientras unos querrán resignificar las huellas del paso del tiempo, unificando la visión del monumento, otros centrarán su atención en intentar capturar en esos dibujos precisamente esas huellas temporales de la mejor manera, utilizándolos como guías para la comprensión del pasado.

\section{LOS PRIMEROS LEVANTAMIENTOS MONUMENTALES DURANTE EL SIGLO XVIII: ENTRE EL INTERÉS COLECCIONISTA MONÁRQUICO Y LA TUTELA DE LAS ACADEMIAS}

El primer viaje con intención anticuaria promovido por la Academia de la Historia en época de Fernando VI, siendo su director Montiano y con el respaldo del marqués de Ensenada, lo protagonizó el erudito anticuario marqués de Valdeflores, Luis José de Velázquez de Velasco, entre 1752 y 1765. En este pionero registro de las antigüedades de España los restos arquitectónicos solo eran un aspecto más de un viaje de descubrimiento de nuestro pasado nacional que debía legitimar a la propia monarquía como institución. En lo relativo a los restos arquitectónicos, lo prioritario iba a ser durante décadas para los académicos, influidos por el vivo debate europeo sobre la regeneración de la arquitectura clasicista, conseguir unas medidas lo más exactas posibles para la descripción de los monumentos antiguos. Los primeros dibujos en España se habían iniciado con el deán Martín para el teatro de Sagunto en 1705, tras pasar una larga estancia en Roma e influenciado por el nacionalismo anticuario de Montfauçon (Mora 1998). En el llamado Viaje de la Antigüedades de España por primera vez se pagaba a un dibujante para un proyecto de este tipo y el elegido fue Esteban Rodríguez, que en esos momentos trabajaba como peón de albañil en las obras del Palacio Real (Maier \& Manso 2015, 52 y 669) y era nada menos que hermano del arquitecto Ventura Rodríguez, que acababa de ser nombrado director de los estudios de Arquitectura de la Academia de San Fernando en unos momentos en que se estaba dando el paso del tardobarroco, todavía muy enraizado en los gustos gremiales populares, al nuevo lenguaje clasicista propio de las minorías ilustradas. Los medios técnicos utilizados por Rodríguez fueron muy insuficientes en relación con lo estipulado por la moderna metodología mostrada por Antoine Desgodetz en su libro de referencia en toda Europa Les édifices antiques de Rome dessinés et mesurés très exactement, editado en París ya en 1682 (Celis 1998), en este caso se sabe que Rodríguez solo utilizó una brújula, un Vitrubio en castellano y se supone que compás, regla, lápiz y plumilla, aplicando aguadas grises.

Las instrucciones en relación al modo de representación gráfica dados a Velázquez se centraron casi exclusivamente en el tipo de módulo que debía aplicarse para medir los monumentos, buscando la mayor exactitud posible y una escala fija, algo que todavía preocupaba a las instituciones más interesadas en los aspectos arqueológicos de Francia e Inglaterra. Debía utilizarse un pie de hierro facilitado por el propio director de la Academia (Maier \& Manso 2015, 678) basado en el pie castellano, lo que finalmente no pudo ser viable. En principio se trató de comprobar el verdadero tamaño del pie español usando como referencias en la medición la vía emeritense, como había ya intentado Nebrija y el maestro Pedro de Esquivel, pero todos los restos materiales sobre los 
que esperaban basarse habían sido desfigurados con el paso del tiempo y fue imposible. Los monumentos hubo que medirlos con los valores del pie romano antiguo del Capitolio (Maier \& Manso, 2015,72 ) tal como se había establecido por la multitud de levantamientos realizados en Roma en los últimos siglos. Cuando el terreno lo permitió, se empleó la máquina óptica o cámara oscura facilitada por el propio Ventura Rodríguez (Salas Álvarez 2003-05, 90).

Velázquez tuvo muchos problemas con la actitud negligente de Rodríguez, que trabajó solo de 1752 a 1754, por considerar, además, que su dibujante no tenía los conocimientos de geometría necesarios: «no sabe levantar un plano, ni medir de lexos, ni usar de la plancheta (Maier \& Manso 2015, 50-53). A pesar de ello terminó siendo el autor de la mayoría de los dibujos de arquitectura, aunque posteriormente colaborarían otros dibujantes en mayor o menor medida. El problema, en realidad era que a esos dibujantes, provenientes del campo de la praxis constructiva, no estaban involucrados todavía en los debates teóricos de las academias europeas y su intento de utilizar la arquitectura romana como referente para una "purificación» del supuesto lenguaje universalista vitrubiano, que consideraban había ido degenerándose. La obra de Valdeflores no se publicó en su momento al caer en desgracia política. La mayoría de sus dibujos se consideran hoy perdidos y los que conocemos son copias realizadas al principio del siglo XIX para integrarlos en los Viajes literarios de Cornide, algunos de los cuales se atribuyeron erróneamente a Melchor de Prado Mariño. Lo más destacable serían finalmente los dibujos epigráficos y no los arquitectónicos.

Una segunda colección importante de dibujos de la Antigüedad española que queremos resaltar aquí será la dedicada a Mérida entre 1791 y 1794 por encargo del pragmático conde de Floridablanca, pensando en futuras excavaciones. El elegido para la tarea fue Manuel de Villena y Moziño, un militar marino de origen portugués. Formado en la Escuela Náutica, había sido el primer maestro de Dibujo y Fortificación en la Escuela de Guardamarinas de Cartagena en 1777. Villena, aunque en sus láminas dibujadas hizo un estudio material de los restos (figura 1), parece que luego no se detuvo en comentar estos aspectos constructivos con mayor profundidad. Se enfrentó a un teatro de Mérida que ya se había empezado a excavar, pero no siguió el modelo de las restauraciones ideales, por no decir mejor «imaginadas», introducidas en los dibujos de Valdeflores (Salas Álvarez 2003-05, 94). La actitud de Villena, por su propia formación, respondía a unos intereses mucho más técnicos y no asumió las posturas cercanas al mundo del anticuariado de Valdeflores. A pesar de sus propios deseos, Villena no pudo seguir excavando para mejorar las mediciones porque el interior del teatro estaba dedicado a cultivos agrícolas particulares.

El total de los levantamientos de Villena no han sido dados a conocer hasta fechas muy recientes (Canto 2001, 96) por haber sido en su día informados negativamente por la recién creada Sala de Antigüedades de la Academia de Historia. Fue Bosarte, entonces también secretario académico de la Academia de Bellas Artes de San Fernando desde la que había impulsado la renovación de la enseñanza del dibujo en las provincias, el que hizo la primera recepción de los dibujos de Villena. Los valoró sin entrar en detalles, reconociendo que nunca había visitado Mérida. Bosarte no había dudado en calificar en su día los dibujos de Mérida del viaje de Valdeflores, realizados en pequeño formato y a pluma, como mezquinos e inexactos, pero a Villena lo único que le reprochará es que hubiera aplicado la vara castellana y la toesa francesa, muy usada entonces por los marinos y los ingenieros, para sus mediciones, esgrimiendo que los «anticuarios suelen usar el pie romano» (Canto 2001, 112). Habría que recordar que, durante el siglo XviII, los levantamientos de los ingenieros militares fueron considerados el paradigma del mayor rigor y objetividad de su época frente a los de arquitectos académicos pues se asumía, ya entonces, que estos últimos siempre añadían algo proyectual, algo de restauración ideal a sus planos. Cornide, académico miembro de la Sala de Antigüedades, tampoco elegiría el pie romano en sus dibujos encargados por la Academia de la His- 
toria por esas fechas y seguirá la misma metodología de levantamiento de Villena en el plano de la basílica de Segóbriga (Canto 2001, 114).

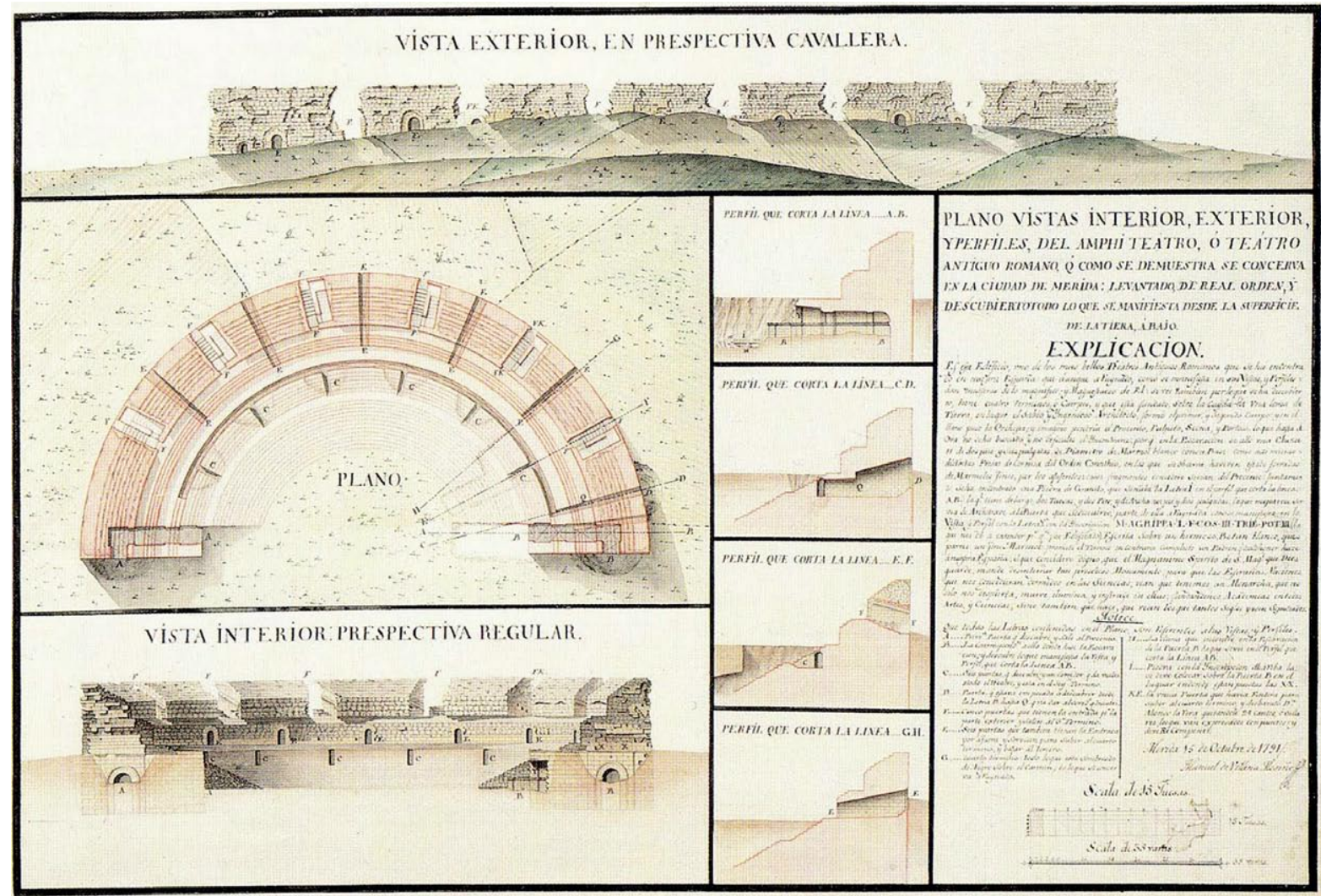

Figura 1. "Plano. Vistas interior y exterior y perfiles del Anphiteatro o Teatro antiguo romano... de Mérida». Manuel de Villena y Moziño. (Fuente: Canto 2001, lám. 2).

La insistencia de Bosarte sobre el tipo de módulo elegido, que era en esos momentos, no lo olvidemos, el máximo representante de la enseńanza de la arquitectura en San Fernando, nos habla del deseo de uniformar los datos métricos obtenidos de las ruinas antiguas con el fin de extraer posibles leyes de racionalidad, $y$, en última instancia, normas para proyectar, que pudieran aplicarse pedagógicamente a la renovación de la arquitectura del momento, incluso por encima de la realidad que pudieran encontrarse in situ. Esta actitud «interpretativa» de las ruinas ya sabemos que fue algo fue muy frecuente en los levantamientos de la Roma clásica desde Serlio, buscando teorizar sobre las proporciones, o de Palladio, persiguiendo la comprobación de las medidas, hasta llegar a los numerosos referentes de la primera mitad del siglo XviII, y dejamos aquí al margen la visión radicalmente subjetiva generada por las ruinas como género pictórico desde el siglo Xviı que llevarían a las vedute y los capricci (Celis 1998). Es por ello que los arquitectos dibujantes, ya a mediados del siglo XVIII, mientras que reproducían las ruinas arquitectónicas en su visión de conjunto con bastante realismo, el fragmento, una basa, por ejemplo, se restituía absolutamente. Para hacer más confuso el panorama, se empezó pronto, desde Carlo Fontana, a grabar dibujos experimentando 
con distintos tratamientos gráficos: las restituciones ortogonales se mezclaron con la aplicación de conceptos perspectivos y de efectos claroscuristas de gran carga emocional, propios de la pintura. Todo ello culminaría en la compleja obra de Piranesi y sus seguidores.

Conocedores de estos debates y publicaciones, los académicos de la Historia de la Sala de Antigüedades, cuando hicieron el informe final del trabajo de Villena, consideraron buenos los dibujos, pero les imputaron «carecer de explicaciones, vistas, discursos y juicios críticos para que sirvan de auxilio a la Historia, sin cuyo requisito solo serían útiles para los profesores de Arte» (Canto 2001, 111-116). Es muy relevante este comentario porque manifiesta la división de intereses que guiaban a las dos academias en el acercamiento a los restos del pasado. En la de Historia su interés era más propiamente «arqueológico» y en la de San Fernando más estético, buscando modelos que sirviesen de referencia, de ahí el interés por añadir siempre las restituciones ideales, profundamente intelectualizadas, de los monumentos. El informe culminaba sugiriendo que si desde el gobierno (Floridablanca ya había caído en desgracia) se querían hacer futuros patrocinios y excavaciones de antigüedades debían estas ir acompańadas de comisionados (académicos, se entendía) de «reconocida literatura e inteligencia que bajo un método uniforme trabajen para que se hagan con utilidad». Es evidente la pugna ya establecida desde el principio por ir delimitando competencias, objetivos y metodologías entre las academias y de estas frente a la monarquía como institución promotora directa (García Sánchez 2007).

El siguiente gran proyecto de viaje para dibujar los restos del pasado clásico nacional fue el de José Ortiz y Sanz, que vivió en Roma de 1778 a 1784, donde asistió a excavaciones arqueológicas, consiguiendo además traducir en 1787 por primera vez directamente del latín al castellano el tratado de Vitrubio. En Italia intentaría sin éxito hacer vaciados de los restos romanos para que España fuese «la primera nación» que tuviese una colección donde pudieran estudiar arte los arquitectos sin tener que ir a Roma. Nombrado a su vuelta Bibliotecario Real, en 1788 presentó a Godoy y Carlos III el proyecto titulado Viage arquitectónico-anticuario por España, que en principio fue aprobado tras informar favorablemente el Conde de Campomanes, proyecto con el que pretendía culminar lo iniciado por el marqués de Valdeflores. En 1787, y ya académico de San Fernando, publicaría un preludio a dicho proyecto. En él criticaba los medios gráficos utilizados por los dibujantes del padre Flórez, impulsor de la monumental obra España Sagrada, en relación con lo referente a las antigüedades clásicas y que había empezado a publicarse a partir de 1747: «el modo que los han producido está tan lejos de satisfacer el gusto y deseo de los Artistas, en especial arquitectos, que más presto les ha aumentado las ansias de verlos dibujados y medidos artísticamente y con inteligencia de partes» (Canto 2001, 41). En realidad, Flórez recopiló en los tomos que dirigió dibujos de los más variados y desiguales colaboradores (Salas Álvarez 2009).

Ortiz explicaba acto seguido cómo debían sistematizarse a su juicio esos levantamientos de los monumentos nacionales:

«Se ha de tomar geométricamente las plantas y alzados de todos los edificios Griegos y Romanos que quedan esparcidos en varios parajes de Espańa, enteros o en ruinas... de todos se ha de hacer crítica rigurosa y fundada de los que fueron, en qué tiempo, y por qué gentes se edificaron, según ofrezca el estilo formal y material que los nacionales usaron en sus obras Arquitectónicas. Obsérvese la cantidad y calidad de los materiales que empleaban: la varia combinación o colocación de ellos: las dimensiones de los sillares, y demás circunstancias que presenten y puedan ser útiles para la entera restauración del arte de edificar. En todos los monumentos considerables se suplirá la parte derruida, por la guía de lo que reste, distinguiéndolo en los diseños. Lo mismo se hará de uno a otro edificio Gótico, Árabe y aun posterior, que tenga alguna recomendación o circunstancia notable, y que pueda prestar a la Arquitectura, Historia, Anticuaria etc. Para la exactitud de las medidas se harán excavaciones y desmontes oportunos.» (Canto 2001, 42) 
Parece que Ortiz intentaba que se asumiese por fin la enseñanza de Desgodetz, el cual había logrado que el dibujo arquitectónico sirviera para algo más que la reconstrucción ideal de los monumentos de la Antigüedad, como había sido lo habitual desde hacia varios siglos. Este arquitecto francés desarrolló una metodología más empirista donde el interés principal era el análisis, la exactitud, la restitución real de las medidas de la arquitectura y no su interpretación apriorística basada en cánones estéticos predeterminados. Desgodetz asumió en sus dibujos el paso del tiempo por el edificio estudiado, iniciando una sutil diferencia en relación a la actitud hacia los dibujos monumentales entre teoría de la arquitectura e historia de la arquitectura, es decir, entre los dibujos trabajados para que sirvieran como modelos de imitación y valores atemporales de inspiración, y los dibujos reproducidos esencialmente como testimonios arqueológicos (Celis 2006, 86).

Finalmente Godoy y el nuevo rey Carlos IV se inclinarían por apoyar el proyecto de Laborde, pero antes de comentar el significado de Laborde en España hay que mencionar la excepcionalidad que supuso el proceso de elaboración y posterior publicación de la obra Antigüedades Arabes de España, organizada desde la Real Academia de San Fernando. El origen del proyecto de dibujar los restos árabes fue muy colateral, como era de esperar por esas fechas, y poco ambicioso en sus inicios (Rodríguez Ruiz 1992, 35). Primero, en 1756, se decidió la realización de unas copias de las pinturas con los retratos de los reyes nazaríes que decoraban las bóvedas de la Sala de los Reyes en el Patio de los Leones, encargándosele a un pintor local, profesor de la recién creada Academia Provincial de Bellas Artes de Granada, Diego Sánchez Sarabia. En esta decisión tuvo un gran peso el historiador y entonces secretario general de la Academia de San Fernando, Ignacio Hermosilla, que había tenido vinculación universitaria con Granada y era conocedor de la lengua y la cultura árabes.

El envío inicial de Sarabia gustó a la Academia madrileña, que le amplió su encargo a una serie de levantamientos tanto de la arquitectura palaciega alhambreña como de sus temas ornamentales y epigrafías. El trabajo de Sarabia fue un conjunto de imágenes ideadas como álbum de coleccionista (Rodríguez Ruiz 1992, 37). No siendo arquitecto profesional, sino pintor, no tuvo prejuicios en ponerse al servicio de la arqueología en clave anticuaria, aislando la decoración del contexto arquitectónico, sin imponer los prejuicios estéticos propios del discurso académico neoclásico del momento.

Mientras realizaba esos dibujos, Sánchez Sarabia estuvo implicado en supuestos hallazgos encontrados en la Alcazaba alhambreña, que se aseguraron, falsamente, provenir de etapas muy remotas, casi bíblicas, lo que produjo un gran revuelo que terminaría en sonoro juicio condenatorio. Se piensa que Sarabia, como colaborador de esta fabulación, buscaba dar respuestas a sus inquietudes locales sobre los orígenes de la Alhambra sin tener así que enfrentarse a una comprometida justificación que en esos momentos pasaba por aceptar esta arquitectura árabe como simple degradación del paradigma clásico grecolatino (Rodríguez Ruiz 1992, 62). Los dibujos arquitectónicos de Sarabia de esta segunda entrega se han perdido hoy prácticamente todos, pero fueron abiertamente rechazados por los académicos cuando los recibieron por no tener escala de ningún tipo. La Academia solo rescataría años después de Sarabia los dibujos figurativos para la edición de las Antigüedades Árabes de España, publicada finalmente en 1804.

Por todo ello, en 1766 se tomó la decisión, en la que debió de volver a intervenir Ignacio Hermosilla, de enviar al arquitecto académico José Hermosilla, su hermano, que no olvidemos era también ingeniero militar y había escrito un tratado de Geometría con Ventura Rodríguez. A Hermosilla le acompańaron dos aventajados alumnos Arnal y Villanueva, para hacer nuevos levantamientos aplicando los criterios que creían necesarios "para formar un juicio cabal del método de edificar de los árabes» (Rodríguez Ruiz 1992, 37). Delfín Rodríguez Ruiz ha dejado claro cómo estos arquitectos se aproximaron al levantamiento analítico de la Alhambra reflejando un posiciona- 
miento teórico apriorístico, basado en su formación académica clasicista. Rodríguez Ruiz insiste en que no pretendieron «evocar» la arquitectura árabe española, aprender de ella, ni mucho menos reconstruirla, sino llegar a conocer los principios compositivos y formales de la estructura original en planta mediante un ejercicio de abstracción que aplicó la disciplina gráfica basada en los métodos vitrubianos de análisis y simetría compositiva. Necesitaban aclarar estos conceptos previos para explicar las posteriores intervenciones como el palacio de Carlos V.

La potencial belleza del monumento debía buscarse a su juicio en los elementos arquitectónicos, en la composición, frente a lo decorativo u ornamental que se considerará, tanto en el texto explicativo que acompañó los planos, como en el tratamiento y elección de los dibujos, algo accesorio y arbitrario. Su interés era encontrar en la Alhambra una fachada «principal» e intentaron traducir la arquitectura árabe a los códigos académicos, buscando el «orden árabe», de ahí su énfasis en los capiteles y en especificar canónicamente el arco de herradura (Rodríguez Ruiz 1992, 96). En algunos momentos, incluso, Hermosilla y sus dibujantes parece que intentaron, casi de manera inconsciente, buscar una lógica compositiva interna, reflejo de su propia formación académica, relacionando sus dibujos con la planta de El Escorial, en cuyo levantamiento había estado implicada la Academia no hacía mucho. Sobre la lámina X, que reproduce el conjunto de los palacios nazaríes, superpusieron un nuevo dibujo que parece «regularizar» ortogonalmente de manera forzada una hipotética planta general que parece sugerir sutilmente debió tener en origen (Ortega 2007, 8).

Para Almagro $(2015,19-21)$ sería resaltable el gran esfuerzo realizado y la incorporación a los dibujos de escalas, aunque estas fueran poco usuales, así como el uso de la plancheta, cuadrante geométrico, niveles, cadenas eslabonadas en pies, pértigas, etc. para poder acceder a espacios difíciles. Sin embargo, no pudieron sustraerse de ir acumulando irregularidades en las mediciones, que terminaron introduciendo errores sobre todo en las secciones, mucho más complejas de dimensionar. Jiménez Martín $(2015,36)$ considera a su vez que utilizaron recursos pictóricos, buscando mayor densidad de detalles, usando sombras propias y arrojadas para dar tridimensionalidad a los alzados, y valora que se realizaran mucho antes de las publicaciones iniciadas en 1799 por Gaspard Monge, considerado el inventor de la Geometría Descriptiva y concretamente del sistema diédrico de representación. Jiménez subraya la dispersión de las unidades de medida de esa época, especialmente en España, situación que no se empezó a enderezar hasta que se consideró obligatorio el uso de tablas de equivalencias en 1852, tras asumirse el Sistema Métrico Decimal desde 1849 con Isabel II, y a pesar de que ya estaban listas esas tablas para aplicarse desde 1798.

LAS PRIMERAS REPRESENTACIONES DE NUESTRA EdAD MEDIA: DESAMORTIZACIÓN Y ROMANTICISMO

Cuando vaya avanzando el siglo XIx, el debate relacionado con las medidas arquitectónicas dejó de tener un interés relevante $y$, poco a poco, con el relativismo que la crisis del dogmatismo clasicista trajo consigo, aparecerán los primeros estudiosos interesados en la arquitectura medieval cristiana, aunque su acercamiento fuese en sus inicios tangencial. Empezarán basándose en sus propias impresiones visuales sobre el terreno y, esencialmente, en crónicas y documentos escritos. La aproximación sería, pues, ante todo filológica. Jovellanos, Ponz y Bosarte buscaban «comprender» la arquitectura de los siglos medievales, que denominaban genéricamente como gótica, porque les resultaba fascinante, pero aún profundamente perturbadora por sus ignotos orígenes. Faltaban referencias. Deberían pasar al menos dos décadas para que los estudios de arquitectura medieval desarrollados por las sociedades arqueológicas francesas con personajes como Caumont en provincias, o Didron desde París, y, sobre todo, Viollet, llegasen a calar en nuestro país como referentes (Ordieres 1995). 
En esos años todavía, los documentos históricos, descontextualizados de la materialidad física real de los restos y sin apenas referencias gráficas, llevarán a aquellos que se acerquen a estas etapas de nuestra arquitectura a elucubraciones muy distorsionadas tales como los posibles orígenes arábigos del gótico, ocultando a duras penas un trasfondo nacionalista. Juan Manuel Inclán Valdés será el primer arquitecto que se atreverá a escribir en 1833 sobre ello en su obra Apuntes para la historia de la arquitectura y observaciones sobre la arquitectura que se distingue con la denominación de gótica, y lo hará, curiosamente, sin presentar un solo dibujo ni levantamiento, reproduciendo directamente los escritos de su paisano Jovellanos. Fue director de Arquitectura de San Fernando y director de la nueva Escuela de Arquitectura desde 1844 y hasta su muerte. Representaría, pues, el enlace entre la antigua enseńanza de la Academia y la nueva enseńanza, también historicista pero de matriz medieval.

Solo un par de años más tarde de la salida del libro de Inclán, en 1835, el proceso desamortizador provocó con fuerza la necesidad de comprender nuestra arquitectura medieval. Ahora sí que surgirá un acuciante deseo de capturar en imágenes estos monumentos medievales, pero serán, de nuevo, pintores los que den el primer paso. Pintores con pasiones anticuarias, considerados por sus contemporáneos, precisamente por este esfuerzo de redescubrimiento plasmado en sus láminas, los primeros "arqueólogos» medievales. Esta arqueología primitiva "cristiana» no necesitaba tanto excavar como redescubrir o aprender a mirar e interpretar los restos de estos siglos medievales.

En la década de los treinta y cuarenta, un puñado de personalidades de ambiguo perfil profesional va a intentar comprender, de manera altamente autodidáctica pero con verdadero ardor de neófito, nuestra historia de la arquitectura medieval. Se dará una colaboración estrecha entre ellos, potenciándose las habilidades y formación de cada cual. Sentirán enseguida la necesidad de difundir los primeros resultados de sus estudios e indagaciones y lo harán a través, primero, de efímeras revistas con escasos medios editoriales y gráficos y, un poco después, mediante colecciones de grabados litográficos, deudores, sobre todo, de dos grandes proyectos editoriales franceses, de obligatoria referencia dadas las influencias directas que tuvieron sobre los futuros dibujantes españoles de monumentos. El primero, Voyage pittoresque et historique de l'Espagne de Alexandre Laborde (1806-1820), se pergeñó antes incluso de la francesada, y en él su director haría coexistir en sus ilustraciones una doble visión ya comentada: la restitución ideal, geométrica, tomada en ocasiones de los estudios previos españoles, e imágenes ya absolutamente distintas, que buscaban conscientemente trasmitir los valores pintorescos, y aun sublimes, de monumentos y paisajes para movilizar nuevas sensaciones y emociones, captando la atención del público. Estos últimos dibujos serán fundamentales para hacer surgir y visibilizar una nueva sensibilidad hacia el pasado medieval.

Laborde contrató por primera vez a arquitectos para realizar este tipo de dibujos, destacando François Ligier, Moulinier y Jean Lutin Vauzalle, al que se denomina "pintor de arquitecturas» (Salas Álvarez 2003-05, 98). Laborde, además de ser en muchas ocasiones el que decidió los ángulos y los encuadres de los dibujos, hizo un buen número de ellos, no dudando en introducir restauraciones ideales parciales en los monumentos clásicos que todavía obsesionaban, pero sin explicar qué pasos habían seguido para llegar a ellas. Las arquitecturas medievales se recogieron de forma efectista pero aún sin reintegraciones, haciendo énfasis en su valor de ruina, en su decadencia, o bien vinculándola a paisajes pintorescos. En lo tocante al arte árabe seguiría muy de cerca a Hermosilla, pero apreciándose ya el nuevo interés que suscitaban (Gámiz \& García 2012).

Otra decisiva influencia temprana francesa en España fue la del Barón Taylor, carente de una concreta formación arquitectónica o arqueológica, pero a quien sus celebérrimos Voyages pittores- 
ques et romantiques dans l'ancienne France, magno proyecto que arrancó ya en 1820, le convertirían en la referencia obligada para la primera generación de dibujantes y artistas románticos europeos, y, por supuesto, españoles que querían captar los restos del pasado nacional. Taylor denunciaría recurrentemente los aspectos decadentes que sufrían estos monumentos debido a la ignorancia y descuido. En el primer tomo del Languedoc, en 1824, ya había explicado las intenciones que lo guiaban para iniciar una empresa tan ambiciosa: «No somos ni arqueólogos ni historiadores, ni poetas. Nosotros somos entusiastas de los recuerdos del país, nos gusta coleccionarlos». Sus fines eran pedagógicos y estéticos: "abrir un camino nuevo a nuestros jóvenes artistas y a nuestros jóvenes sabios» (Midant 2001, 10). Taylor usará de manera pionera el daguerrotipo y no dudará en contratar, muy significativamente, a dibujantes especializados en escenografías teatrales, caso del gran dibujante Dauzats. Viollet-le-Duc, que se había negado a formarse como arquitecto en la École des Beaux Arts, empieza a trabajar como ilustrador para Taylor con 25 años. Según el propio Viollet, este tipo de ilustraciones se concebían como acompañamientos del texto para ayudar a «fijar» la atmósfera emocional. Buscaron, sobre todo, hacer nacer en el lector «el sentimiento histórico» por el pasado (Midant 2001, 12). Aunque los tomos de su Voyage Pittoresque en Espagne recientemente se ha demostrado que no vieron la luz hasta el año 1850 (Luxemberg 2013), es indudable la influencia determinante que empezó a ejercer la cultura francesa en nuestro país en general y la obra de este personaje en particular.

Las motivaciones emocionales reivindicativas de Taylor serán asumidas por los primeros artistas románticos españoles de vistas monumentales, especialmente Carderera, Villaamil y Parcerisa. De esos dibujantes destacaríamos a Valentín Carderera. Pensionado por el Conde de Villahermosa, tuvo una etapa de formación en Italia, y ya en 1832 sería nombrado miembro de la Academia de San Fernando. Sin ser arquitecto, diseña en 1834 el catafalco funerario para Fernando VII de estilo abiertamente neogótico, como una proclama de lo que estaba por venir. Carderera se relacionará con toda la primera generación de románticos españoles en el Liceo Artístico y Literario que se reunía en el Palacio de los Duques de Villahermosa, y colaborará en las fugaces revistas románticas. Allí conocerá a Pérez Villaamil, con el que tendría actividades comunes como veremos.

El desencadenante que convertirá a Carderera en el primer dibujante español que inicie viajes oficiales para reproducir edificios medievales con un sentido "arqueológico», será la exclaustración y venta de los bienes nacionales de la Iglesia a partir de las medidas liberales iniciadas por Mendizábal en 1835. Se le encarga, ya en 1836, por la Academia de San Fernando, inventariar los monasterios desamortizados de Valladolid, Burgos, Palencia y Salamanca (Calvo Martín 2007-08). En estos primeros momentos del estudio de la arquitectura medieval se insistió mucho en definir al «arqueólogo» como aquel que quería y sabía dibujar dichos restos del pasado, y así se constata en el testimonio de Pedro de Madrazo sobre Carderera, refiriéndose a su actividad durante los años treinta del siglo XIX:

«En aquel tiempo en que aún no se había descubierto, no ya la fotografía, pero ni siquiera el daguerrotipo, un arqueólogo que no supiera valerse por sí mismo del lápiz o el pincel, tenía que hacer necesariamente estudios muy incompletos, y para llegar a comprender los diferentes estilos y dar a sus observaciones alguna clasificación, había de emplear prolijas anotaciones e interminables procedimientos, sometiéndose siempre a datos inciertos o del todo erróneos, como procedentes de artistas no educados para el dibujo arqueológico. Carderera, por el contrario, se servía indistintamente de todos los medios gráficos conocidos, y auxiliado de su fidelísima retentiva, con la cual terminaba la copia del objeto aun sin tenerlo delante, atesoraba rápidamente en sus carteras todos los datos de forma, de color, de materia y de magnitud, y los demás accidentes y pormenores que 
demandaba la diminuta ciencia arqueológica de aquella época, todavía poco exigente.» (Madrazo $1882,110)$

A partir del traslado de la regencia de María Cristina a París, Carderera, como su pintor oficial, pasaría a residir allí al menos de 1840 a 1843 . En este tiempo coincide con personajes como el arabista y epigrafista Pascual Gayangos, clave en el rescate de la documentación medieval procedente de los monasterios suprimidos en España, fondo inicial del Archivo Histórico Nacional. La otra amistad decisiva será la de Mérimée, ya Inspector de Monumentos de Francia, que debió adentrarle en los métodos que se habían empezado a aplicar en la Comission de Monuments Historiques para el estudio de los edificios medievales. La opinión de Mérimée sobre Carderera no deja lugar a dudas sobre la valoración de este como pionero:

«Carderera (...) recorría la Península en medio de los horrores de la guerra civil, explorando los insignes monumentos y gloriosos recuerdos de la patria que parecían un día imperecederos, sin que los peligros, las fatigas y las privaciones fuesen parte a moderar su entusiasmo y a contener su admirable actividad, ilustrando al vulgo acerca de las bellezas amenazadas por su ciego delirio, y acerca de los gloriosos recuerdos que encerraban, exhortándole a conservarlos. Más de una vez tuvo la suerte de evitarlo, y cuando sus esfuerzos no lograban contener tan furiosos instintos de devastación conseguía al menos suspenderlos por breves instantes para reproducir con el lápiz los que muy pronto iba a reducirse a escombros. Así conservó Carderera objetos preciosos, cuya pérdida hubiera sido irreparable, y así reunió en tan expuestos y fatigosos viajes un tesoro de dibujos tomados del natural, tanto más interesantes cuanto que han desaparecido una gran parte de los objetos y monumentos que representan.» (Madrazo 1882, 111)

En cuanto al estilo de los dibujos de monumentos de Carderera (figura 2), Federico de Madrazo le recomendó en 1837 que fuese a ver a Dauzats, que acababa de acompañar al Baron Taylor en un nuevo viaje por España (Lanzarote 2010, 167). Carderera quiso vender sin éxito en los años cuarenta sus dibujos por cuadernillos en Francia, como otros artistas europeos, pero los estudiosos y eruditos franceses valorarían sobre todo de él su famosa Iconografía española y sus estudios tempranos sobre Goya. Sabemos que en alguna estancia en Londres conoció a Owen Jones y en 1841 a Richard Ford (Lanzarote 2010, 168). No fue casualidad que Carderera volviera de París justo en febrero de 1844, coincidiendo con el regreso de la reina regente, y que fuese en junio de ese mismo año cuando se creasen la Comisión Central de Monumentos y las Provinciales. A Carderera se le encargará, junto a Aníbal Álvarez, la sección de Arquitectura de esta nueva institución gubernamental.

Carderera colaborará de 1842 a 1844 en la colección La España Artística y Monumental, del exitoso pintor Jenaro Pérez Villaamil, que financió el Marqués de Remisa, banquero y coleccionista. La capacidad de difusión de la litografía pasa a ser la pieza clave de estas colecciones. La rapidez de salida de la obra obligó a completarla con dibujos de otros artistas, entre ellos Carderera. Se sabe precisamente por un comentario de Richard Ford que Carderera se molestó mucho por no ser citado en algunas de sus láminas, figurando solo Villaamil. Carderera escribiría a Villaamil reclamando su autoría (Arias 1986, 535). El enfado era aún más comprensible si consideramos los penosos traslados necesarios para dibujar estos monumentos in situ. Por su parte, de Villaamil, a pesar de que efectivamente había aprendido de Roberts, cuando le conoció en Sevilla en 1834, a imaginar la realidad en vez de describirla, hay que resaltar sus brillantes dibujos a mano alzada de iglesias y edificios que vio derribar en los años treinta, en ciudades como Madrid, Alcalá de Henares o Guadalajara y que podrían denominarse de reporterismo gráfico por la espontaneidad y soltura, pero al mismo tiempo fidelidad, con que fueron captados. 


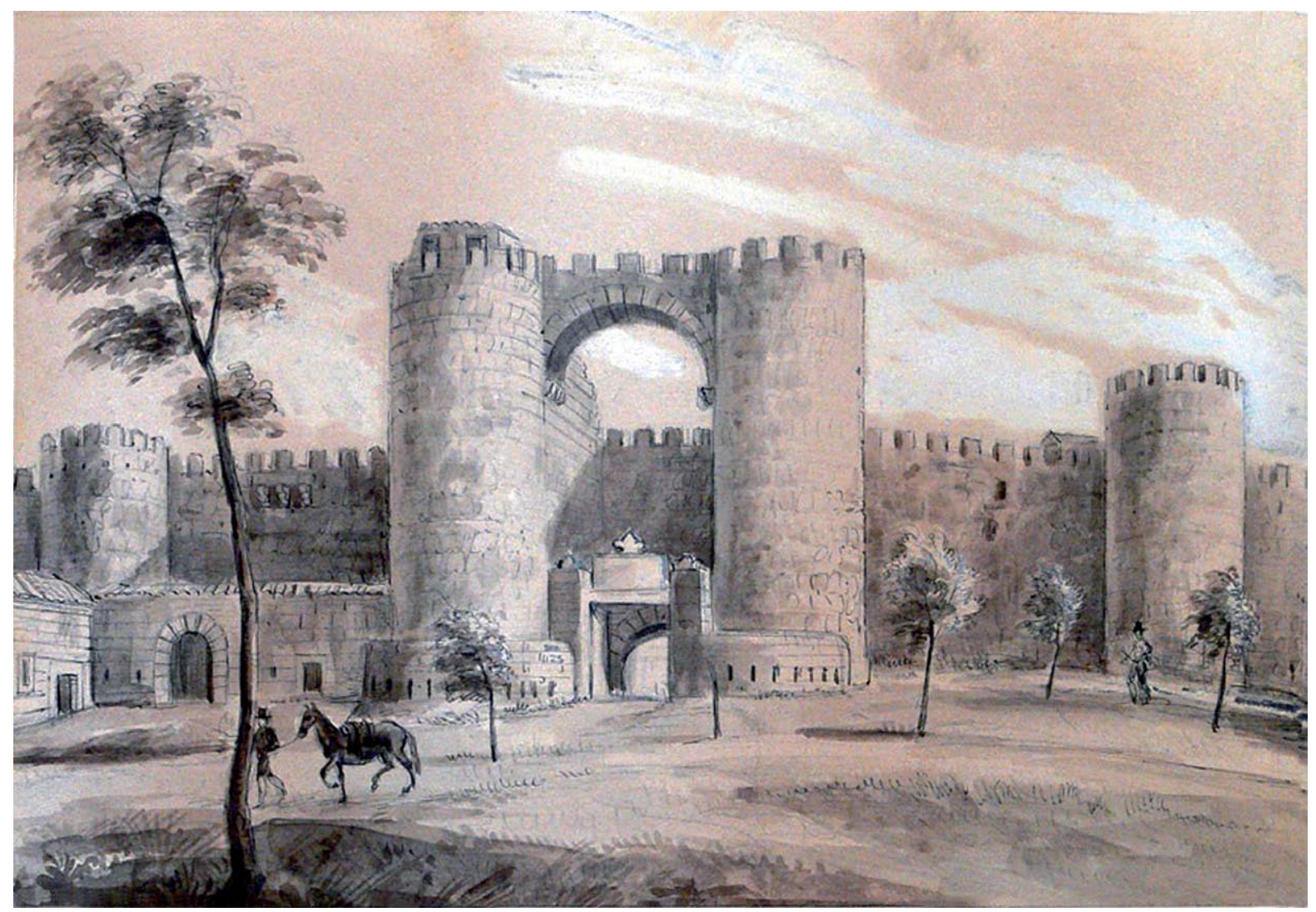

Figura 2. Dibujo de la muralla de Ávila. Valentín Carderera, hacia 1850. Fundación Lázaro Galdeano.

Paradójicamente, Parcerisa, otro de los dibujantes claves del momento, tampoco arquitecto de formación, y conocido por la otra gran colección española de esos años, Recuerdos y Bellezas de España, iniciada por Piferrer, cedió en ocasiones a la veleidad de reintegrar partes de monumentos, a pesar de tener fama de poseer un estilo descriptivo y realista, casi «arqueológico». Los fuertes contrastes lumínicos y el tipo de composición escenográfica de sus imágenes han llevado a pensar que pudo utilizar la técnica del daguerrotipo, mientras que para otros simplemente usó la cámara oscura (Alonso 1999), como casi todos los artistas de esa época. Parcerisa viajaría con Carderera en ocasiones e hicieron grabados conjuntamente (Lanzarote Guiral 2010, 154. Carderera, sin embargo, mucho más investigador y erudito que Parcerisa, inevitablemente terminaría relacionándose con los pocos arquitectos que por los años cuarenta estaban interesados en el estudio de lo medieval. Carderera escribirá en esta ocasión sobre pintura española en el Boletín Español de Arquitectura, revista creada por el arquitecto Antonio Zabaleta, formado en Roma donde se había acercado al mundo de la arqueología, junto a José Amador de los Ríos, en plena reivindicación de los estilos artísticos nacionales.

En el Boletín se daría a conocer también Manuel Assas, uno de los primeros historiadores-arqueólogos medievalistas. Cuando en 1857 se convirtió en director de la revista Seminario Pintoresco Español, publicó una serie de artículos sobre «Nociones fisiognómicas-históricas de la arquitectura en España», que había dictado previamente en el Ateneo madrileño entre 1846-47, en los que ma- 
nifestaba ya en el título su preocupación por otorgar categoría científica a la historia de la arquitectura mediante la deducción morfológica comparada de sus elementos, intentando aplicar los estudios positivistas y naturalistas al estudio de los edificios. En estos artículos Assas añadió grabados a partir de dibujos realizados por él mismo. Había recibido clases de dibujo lineal y de arquitectura, justamente de Antonio Zabaleta en el Instituto Cántabro en Santander, de donde eran los dos, entre 1838-39. Los dibujos del Semanario Pintoresco Español no destacaron por su detallismo debido a que estas primeras revistas románticas, por su enorme precariedad económica, solo pudieron utilizar la xilografía, una técnica de grabado esquemática en sí misma. Assas, sin embargo, había publicado ya su Álbum de Toledo en 1848, en el que había definido por primera vez la noción del estilo visigótico y donde reproduciría dibujos mucho más elaborados y con un acercamiento gráfico expositivo más analítico que hay que relacionar con el proyecto que iba arrancar ya en la colección Monumentos Arquitectónicos de España.

\section{La relación entre la creación de la Escuela Especial de Arquitectura y la colección DE MONUMENTOS ARQUITECTÓNICOS DE EsPAÑA}

El año de 1844 no fue solo un año clave por la creación de la Comisiones Provinciales de Monumentos, sino que también se puso en marcha una Escuela Especial de Arquitectura que arrebataba en gran medida el control de la enseńanza a la Academia de San Fernando. Había que unir fuerzas para enfrentarse al colosal reto latente que las medidas desamortizadoras habían puesto al descubierto. El influjo de la experiencia francesa en relación a la salvaguardia monumental era evidente, pero pronto se vio que el conocimiento y preparación de los miembros de las Comisiones Provinciales de Monumentos no era suficiente para enfrentar dicho reto en el que se exigía por normativa realizar toda clase de dibujos y levantamientos (Ordieres 1995). Una nueva Escuela de Arquitectura, con la necesaria modernización de sus planes de estudios, podría aportar los cuadros de especialistas necesarios. Era la constatación de un cambio de rumbo pedagógico que se abría ya claramente a un historicismo basado en los estilos del pasado medieval nacional. Había que recabar material pedagógico, dibujos, vaciados de los que partir. Por ello, en 1848 se organizará un Viaje Arquitectónico con los alumnos de la nueva Escuela, y el político-historiador José Caveda será el encargado de redactar lo que se denominó Ensayo histórico sobre los diversos géneros de Arquitectura empleados en España desde la dominación romana hasta nuestros dias, primer intento de periodización que sirvió, sobre todo, para dejar patética constancia del enorme vacío de conocimientos que se tenía sobre nuestra arquitectura medieval.

A estas alturas podríamos ya constatar que los arquitectos no llegaron realmente al estudio de la arquitectura medieval sino cuando el levantamiento analítico se empezó a entender, como había pasado de parecida manera en el XVIII, como referencia para la propia pedagogía de la nueva enseñanza de la arquitectura, es decir, cuando fueron espoleados por el deseo de renovar sus lenguajes formales y simbólicos. El inquieto Aníbal Álvarez Bouquel como profesor, y más tarde director de la nueva Escuela, seguiría organizando viajes de estudios con los alumnos, y junto a Zabaleta realizaría uno fundamental a Toledo en 1849. Enseguida, una comisión de la Escuela pedirá al Gobierno que publiquen los resultados que se fueran obteniendo. Ese será el origen de lo que llegaría a ser el gran despliegue editorial y gráfico de la colección Monumentos Arquitectónicos de España.

En 1856 se puso en marcha por fin esta publicación, combinando, por primera vez, a arquitectos profesores de la Escuela y a historiadores «arqueólogos» como Pedro Madrazo y José Amador de los Ríos Serrano, siendo Assas el secretario. Si atendemos los textos resultantes, gran parte de ellos escritos por José Amador de los Ríos, se echan enseguida en falta referencias explícitas a la documen- 
tación y fuentes bibliográficas utilizadas, para caer, sin embargo, en infladas digresiones que parecen querer disimular la falta de conocimientos concretos sobre el edificio en cuestión. Se había ya advertido cuando se inició la colección, con una sinceridad que más bien sonaba a disculpa, que no podría realizarse «una clasificación excesivamente metódica» sino al final de la obra para que pudiera así culminarse el "examen comparativo» de todos los monumentos de España (Bordes 2014, 34). Algo así como que se iría haciendo la historia de la arquitectura española sobre la marcha. La realidad fue que el desorden, y aun el caos, en la salida de los 89 fascículos reinaron casi desde el principio.

Por el contrario, el despliegue gráfico conseguido fue espectacular, con unos medios técnicos de reproducción nunca vistos en España. El desequilibrio entre texto histórico e imagen, que había sido una constante en las otras colecciones, aquí se inclinó de una manera aplastante por lo visual, mostrado el trabajo entusiasta de una nueva generación de arquitectos deseosa de controlar esos lenguajes del pasado. Los métodos gráficos en los levantamientos no fueron unitarios en la colección. Hubo láminas incluso que se abordaron como meros repertorios ornamentales en la línea que había instituido Owen Jones en su Gramática del Ornamento y otros grandes referentes como Semper, Bötticher o Jacobsthal, introduciéndose, gracias a las modernas cromolitografías, una poderosa policromía que ya Hittorf había reivindicado para el mundo clásico. Hubo otra línea gráfica (figura 3) mucho más arquitectónica y con una evidente influencia de los levantamientos iniciados en 1837 en Francia por la Comission des Monuments Historiques, buscando la plasmación de un lenguaje gráfico propio que permitiera representar los monumentos del pasado con finalidades eminentemente restauradoras. Se intentará seguir, pues, una metodología positivista para expresar las características formales de los monumentos, paso fundamental para la definición de la noción de «estilo» como herramienta conceptual, que les resultaría enormemente útil a la hora de interpretar y restaurar los edificios. Se puede afirmar que en esta etapa la restauración arquitectónica terminó convirtiéndose en un verdadero laboratorio de experimentación arquitectónica historicista y en este sentido el sistema de levantamientos y representación fueron decisivos.

La aportación de los considerados en esos momentos historiadores-arqueólogos, especialmente Amador de los Ríos y Madrazo, se limitaron a los textos ya comentados y los dibujos de los profesores y alumnos de la nueva Escuela tuvieron una notable falta de precisión, adolecieron de pitipié, no se relacionaron con ningún tipo de escala, dando por sentado la utilización de unidades de medidas tradicionales como el pie castellano, y carecieron de cotas explícitas, algo que para entonces ya era habitual. En realidad, estos dibujos fueron más una formulación en gran medida conceptual e idealizada de definición estilística, cuyo influjo interpretativo, por la gran calidad de los dibujos en sí mismos, caso de Francisco Contreras o de Jerónimo de la Gándara en relación con la Alhambra, por ejemplo, perduraría durante muchas décadas en la historiografía arquitectónica española.

El uso de la fotografía contribuyó a definir el terreno que le correspondía al dibujo arquitectónico (González Reyero 2007), es decir, deberían centrarse sobre todo en los levantamientos de tipo analítico: plantas, secciones, axonométricas o detalles de difícil reproducción, con introducción convencional de sombras. El dibujo técnico se asumirá a partir de entonces como una necesaria interpretación, en la que subyacerá siempre una teoría previa que dependerá del nivel de conocimientos barajados. Los pormenorizados dibujos de capiteles, por ejemplo, favorecerán el desarrollo del método comparativista, de raíz positivista, análogo al aplicado en los estudios desarrollados hasta entonces por los naturalistas (Choay 1992, 65). Las limitaciones técnicas de la fotografía del momento, como era la necesidad de largos tiempos de exposición para poder capturar las oscuras naves de iglesias, posibilitaron ciertas convenciones de representación idealizada de los interiores de los edificios, que se presentaron siempre despojados de cualquier objeto artístico mueble o de posibles restos de revestimientos decorativos. 


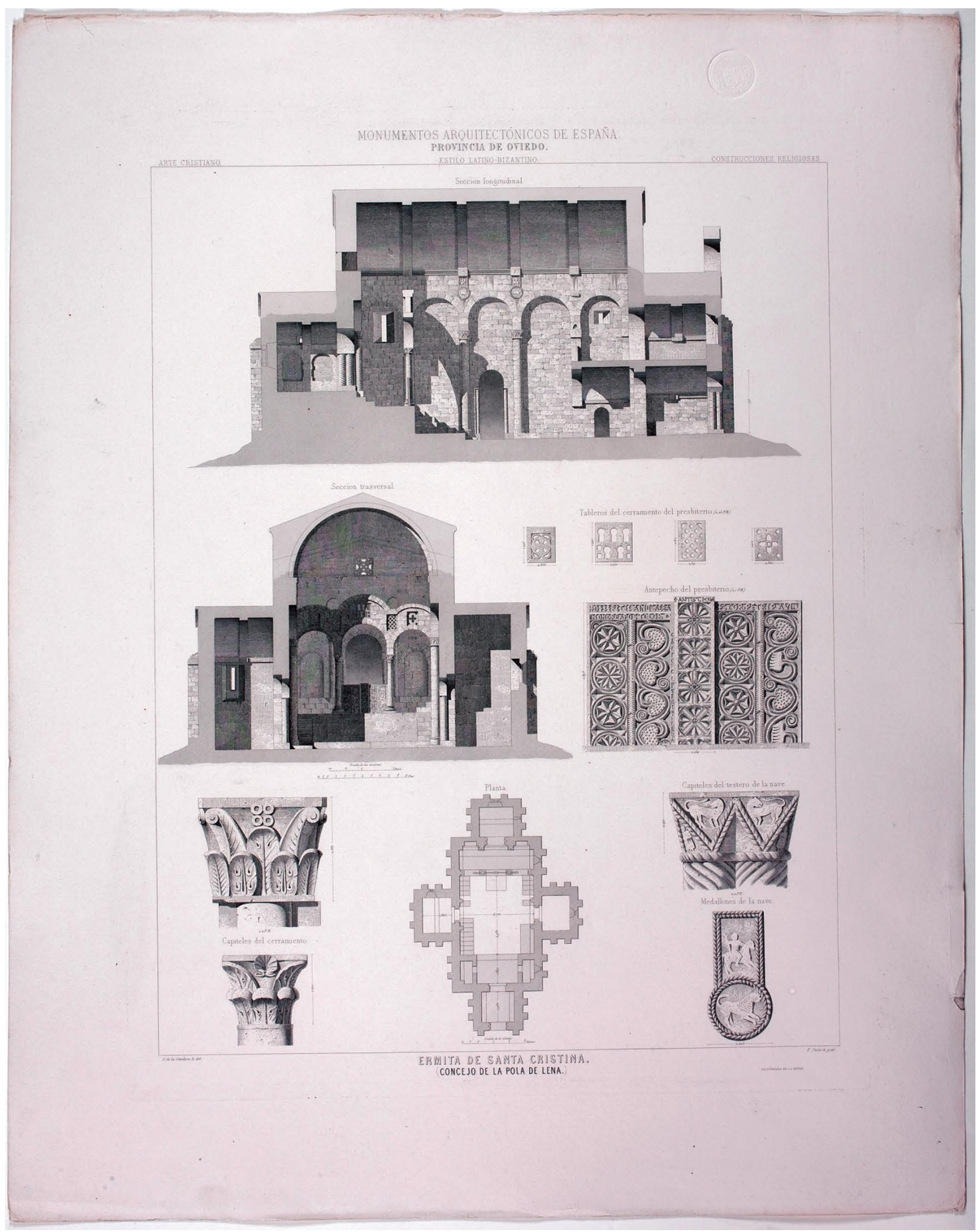

Figura 3. Planta, alzado, sección y detalles de Santa Cristina (concejo de Pola de Lena) dibujo de Jerónimo de la Gándara. Grabador: Enrique Stüller. Monumentos Arquitectónicos de España. 
La Comisión de Monumentos Arquitectónicos de España había redactado unas instrucciones previas para los levantamientos, buscando la máxima fidelidad, por las cuales tenían que indicarse en los dibujos «lo que es en ellos edificio primitivo y lo que pertenece a modificaciones o restauraciones posteriores» (Sánchez de León 1997, 323). Pero en ningún caso se cumplió. Al contrario, los edificios se mostrarán sin huella alguna de deterioro y restaurados idealmente. Este asunto querríamos recalcarlo pues en este tipo de decisiones gráficas estaría implícita la clave del creciente desencuentro que se va a dar en el discurrir de las disciplinas de la restauración arquitectónica y de la arqueología en las últimas décadas del siglo XIx. Veamos un caso que ilustra todo ello y en el que se da además el frecuente binomio hermanos dibujantes-arquitectos o historiadores-arquitectos. Demetrio de los Ríos y Serrano se formará con su hermano José Amador, siendo este responsable de las excavaciones de Itálica desde 1841, y allí se inicia como dibujante mucho antes de obtener su título de arquitecto en 1852.

Desde 1860 a 1875, además de desarrollar una labor incansable a favor del patrimonio sevillano, Demetrio fue responsable de las excavaciones de Itálica y publicará trabajos interesantes desde un punto de vista historiográfico, como su Memoria arqueológica-descriptiva del anfiteatro de Itálica (Ríos 1862), acompañada del plano y restauración del mismo edificio. José Amador debió imbuirle en sus inicios profesionales ciertas exigencias metodológicas y así lo comentaba Demetrio en esta memoria cuando consideraba la «arqueología monumental» una «interesantísima ciencia que enriquecía la historia, la estética y la teoría del arte, ayudando a que no estuvieran expuestas a caer "en los errores de un idealismo infecundo» (Ríos 1862, 8). Sin embargo, el análisis reciente de sus dibujos sobre las ruinas de Itálica suscita entre arqueólogos y arquitectos restauradores actuales la conclusión de que constituyen sobre todo un legado acorde con las convenciones del dibujo arquitectónico de la época. Consideran que muchos de esos dibujos fueron esencialmente ejercicios "de imaginación» compositiva, que intentaban dar una coherencia idealizada a los restos hallados, erróneos en gran medida puesto que no tenían escala, ni acotaciones, aunque usó ya el sistema métrico decimal como profesional «moderno» (Jiménez Martín 2012, 216). Demetrio, llegó a hacer restituciones en las termas de Itálica de 20 metros de altura cuando la cota más alta existente era de 2 metros. A pesar de ello, muchos de sus levantamientos son considerados valiosos testimonios de un primer análisis de estructuras in situ que hoy han desaparecido.

En 1880 Demetrio de los Ríos sustituiría al prematuramente fallecido Juan de Madrazo, también hermano del historiador Pedro de Madrazo, en la restauración de la catedral de León. Demetrio no tendrá inconveniente entonces en evolucionar del racionalismo con el que Juan Madrazo había interpretado la arquitectura gótica del edificio a una atrevida búsqueda de unidad de estilo proyectual, que no podía ser más contradictoria desde el punto de vista arqueológico. Esta postura, sin embargo, fue la más habitual en las décadas finales del siglo XIX por parte de los arquitectos restauradores (Ordieres 1995), cuando se realizaron obras reconstructivas de gran calado arquitectónico, cayendo en la «reapropiación» del monumento por parte del arquitecto restaurador. Es casi imposible discernir hoy todo lo que pudo desaparecer a causa de esas obras y lo que se desfiguró irremediablemente.

El caso de Aníbal Álvarez Amoroso, hijo de Aníbal Álvarez Bouquel, uno de los fundadores de la Escuela de Arquitectura de Madrid, creemos que es sintomático de cómo la relación entre arquitectos, por un lado, e historiadores y arqueólogos, por otro, se fue polarizando en las décadas finales del siglo xix. Recordemos que desde 1865 la Academia de San Fernando había recuperado el control, si no de la arquitectura del presente, si al menos de la del pasado, puesto que había dispuesto el Gobierno que debía informar y aprobar los proyectos de restauración monumentales. Desde los ańos ochenta, y sobre todo noventa, estas comisiones se fueron decantando cada vez más 
hacia posturas proconservadoras y «arqueologistas» como se las denominó entonces, siendo informantes en ellas personalidades como Facundo Riaño o José Ramón Mélida (Ordieres 1995).

Aníbal Álvarez Amoroso fue muy activo como restaurador en el tránsito del siglo XIX al Xx, pero decidió seguir sus preferencias, claramente postviolletianas. Creemos, tras estudiar las memorias que enviaba a la Academia de San Fernando, que su estrategia fue no presentar a la Comisión informante apenas ningún plano detallado y nunca planos del «antes» de sus proyectos de restauración, escudándose siempre en que las labores eran solo de mantenimiento y limpieza. Es ya muy conocido el caso de unos de sus proyectos restauradores, el de San Martín de Frómista, y cómo Gómez Moreno descubrió los desmontes y reconstrucciones que allí se efectuaron, pero actuó parecido en San Pedro de Cervatos en Cantabria, y nos tememos que pudo ser su modus operandi en los demás edificios en los que intervino, entre ellos algunos tan fundamentales como San Juan de Baños, pues no existe en relación a este sino alguna planta firmada por él, y nunca alzados ni secciones, algo inusual si lo comparamos con la profusión gráfica que desplegaron otros arquitectos, ausencia que provoca desconciertos incluso en los arqueólogos que han estudiado el edificio en la actualidad (Caballero 1998, 7 y 17).

Distinto caso, pero también muy ilustrativo de la relación entre arquitectura y arqueología, es el de Adolfo Fernández Casanova que llegaría a ser académico numerario de la de Historia. Entre sus restauraciones destacaríamos aquí, dentro de las realizadas por él en la Catedral de Sevilla, la que debió efectuar con urgencia en la Giralda por haber impactado un rayo en su fachada en 1883. Casanova se lanzó con vehemencia a desarrollar lo que él llamó un análisis "filogenético» de los alminares de esta etapa almohade, siendo el primer arquitecto al que se le costeó un viaje a Marruecos para profundizar en sus estudios. La serie de planos comparativos de alminares que dibujó, conservados en el Archivo de la Administración Central de Alcalá de Henares, hablan de todo este proceso y le sirvieron, finalmente, para justificar que debía restituirse la Giralda a su estado original de época almohade. También es interesante en este sentido, su dibujo de la base del cuerpo de campanas donde Fernández Casanova reproduce con sumo cuidado y detalle los restos árabes decorativos de ladrillo que habían quedado ocultos con la reforma cristiana (figura 4), que le daban la referencia estilística de la que partir para su reintegración, la cual finalmente no fue aprobada por la Comisión de la Academia de San Fernando. Sus aportaciones eruditas y sus posibles contradicciones metodológicas se pueden constatar en su Catálogo Monumental de Sevilla, realizado entre 1907 y 1910.

Entre los más de cincuenta dibujantes de Monumentos Arquitectónicos de España, destacó Ricardo Velázquez Bosco que había sido descubierto gracias a sus grandes dotes como dibujante por Jerónimo de la Gándara. Colaboraría también en esos primeros años de formación con Juan de Dios de la Rada, participando como ilustrador en la Expedición de la fragata Arapiles y en la colección Museo Español de Antigüedades (Baldellou 1990, 42 y 50). Se puede decir que fue un arquitecto que se formó con los arqueólogos más importantes de su tiempo, dibujando y colaborando con frecuencia también con José Amador de los Ríos (Baldellou 1990, 65).

Velázquez llegó a tener una fulgurante carrera que culminó con el encargo de restaurar la Mezquita de Córdoba en la que se volcará de 1891 a 1923 aplicando lo que él consideró estudios exhaustivos arqueológicos que condujeron, como era lo esperable por las fechas, a grandes reconstrucciones en estilo (figuras 5 a y 5b), eso sí, realizadas con el mayor de los cuidados y calidades artesanales. A partir de 1910 también trabajaría en Medina Azahara. Velázquez se lució en múltiples y detallados levantamientos de la mezquita cordobesa y en los planos de sus proyectos de restauración, definiendo espectacularmente el antes y el después con vivos colores, pero, de manera significativa, evitó dejar constancia gráfica muy explícita de aquellas intervenciones en las que hubo de introducir elementos industriales, como las estructuras metálicas de las cubiertas que rehízo, por no considerar que entrara este apartado constructivo en la categoría de lo «artístico». 


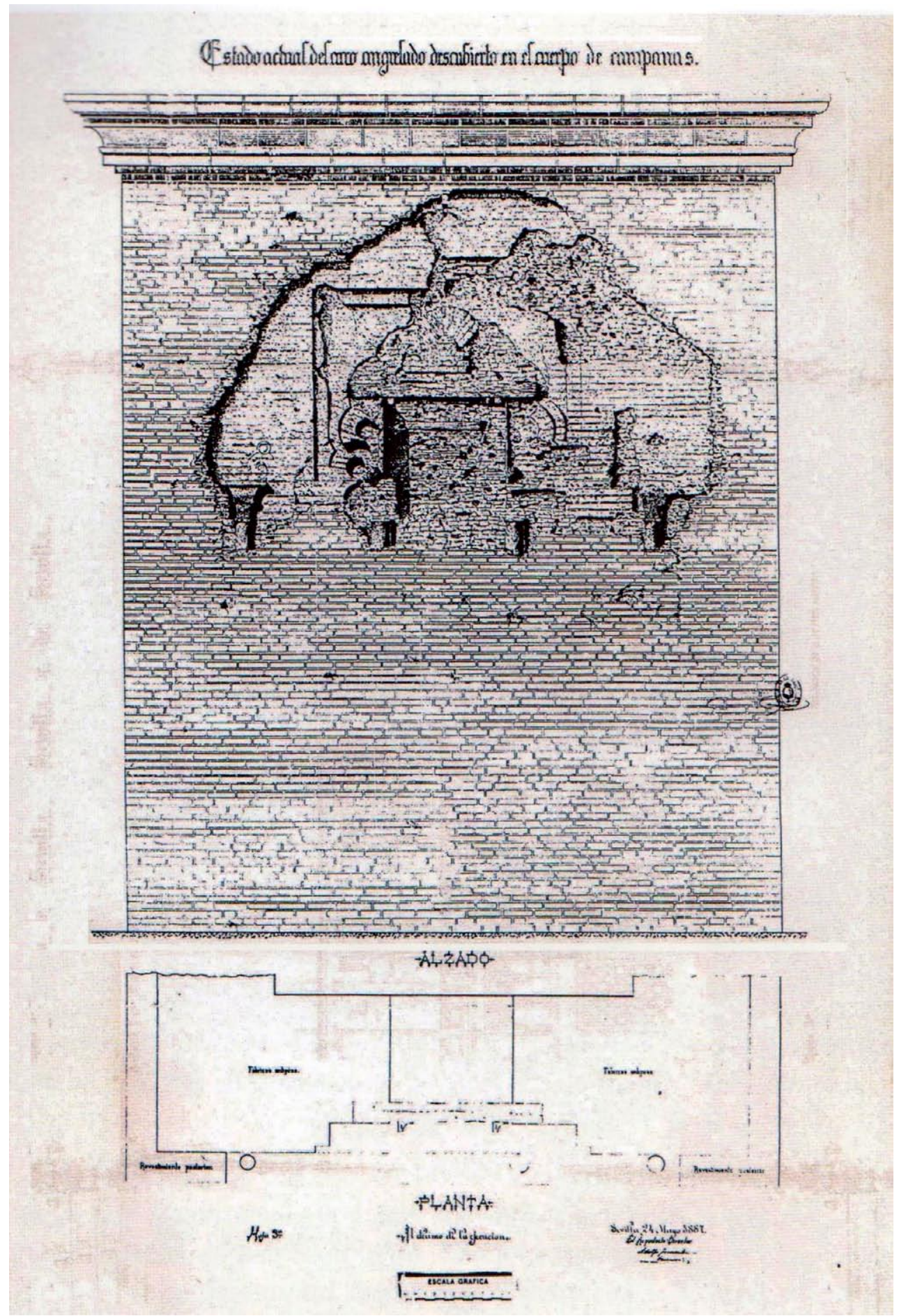

Figura 4. Dibujo de arco árabe angrelado descubierto en el cuerpo de campanas de la Giralda de Sevilla. Adolfo Fernández Casanova. 1887. Archivo General de la Administración de Alcalá de Henares. Sig. 19080-3. 
Como Inspector de Antigüedades y Museos de la Zona Sur, además de por su condición de catedrático de Historia de la Arquitectura en la Escuela de Madrid, tuvo que redactar en 1917 un plan director para la Alhambra por mandato del recién creado Patronato, buscando controlar al arquitecto conservador del momento, Modesto Cendoya, que había llegado a exasperar por sus interminables e infructuosas excavaciones con veleidades arqueológicas de anticuario, sin un programa concreto y con flagrante carencia de dibujos o levantamientos referenciados. El plan director de Velázquez, acompañado de eficaces dibujos, sería el referente inicial a partir de 1923 para el nuevo arquitecto restaurador de la Alhambra, Leopoldo Torres Balbás.
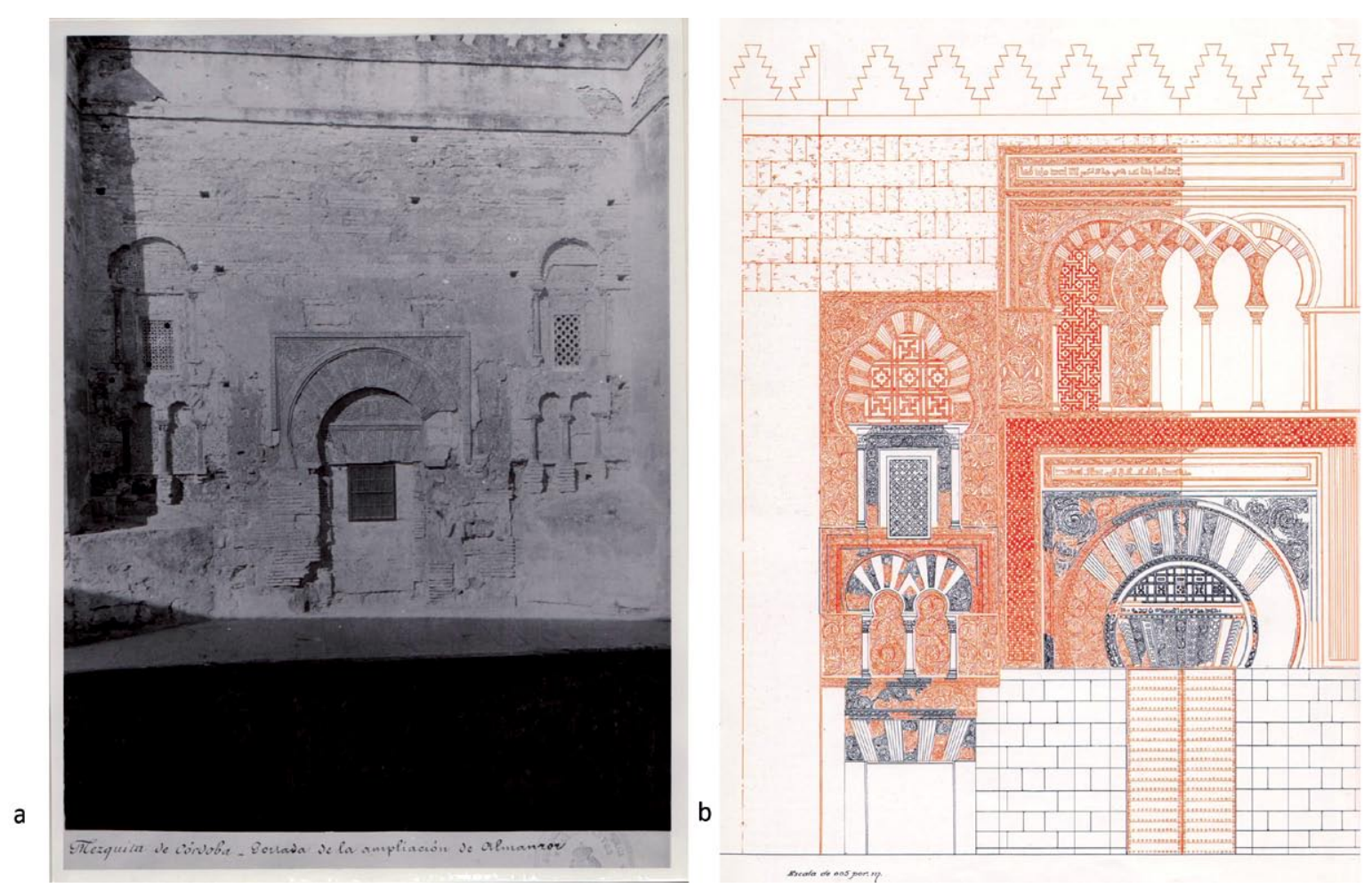

Figuras 5a y 5b. Fotografía de la fachada exterior de la Mezquita de Córdoba antes de la restauración y detalle del proyecto de restauración de Ricardo Velázquez Bosco. 1907. Portada ampliación de Almanzor. Sig. 13181-6. Archivo General de la Administración de Alcalá de Henares.

Finalmente, ya en el primer tercio del siglo xx, la figura de Leopoldo Torres Balbás conseguirá dar un vuelco a la tendencia que hemos ido comentando hasta aquí. Se aúna en una misma persona lo que debería haber sido la mutua colaboración entre arquitectos y arqueólogos. Fue el primer arquitecto que asimiló y puso en práctica las corrientes más modernas arqueológicas de su época, aprendidas en la Junta de Ampliación de Estudios. Realizará, pues, una práctica de verdadera arqueología, pero con el objetivo propio del oficio de arquitecto, algo que han resaltado todos los que le han estudiado. Se considera que convirtió la arqueología en una herramienta metodológica para lograr entender el proceso de construcción de la Alhambra y del Generalife de cara a su restauración. Torres logrará asumir de manera inteligente, gracias a sus grandes conocimientos y su 
capacidad analítica, las metodologías de Pitt Rivers y Flinders Petrie (Vílchez 1988, 28), los padres de la arqueología moderna en el ámbito anglosajón.

Torres Balbás tuvo un verdadero respeto por las ruinas, que no tuvieron sus antecesores. No hizo ninguna obra sin explorar antes el subsuelo y los muros. Asumió de algún modo la estratigrafía, al recoger y clasificar todo lo encontrado en sus obras. Los objetos hallados dejó de valorarlos por sus cualidades singulares anticuarias, de manera que los restos cerámicos, antes desdeñados, se convirtieron para él en insustituibles indicadores, en elementos fundamentales para el desarrollo de un esquema de seriaciones cronológicas comparadas. Se han destacado los factores innovadores de su nueva manera de trabajar y uno de ellos fue, precisamente, la confección de planimetrías con un novedoso tratamiento analítico, que huyendo de lo vistoso, propio de sus colegas anteriores, buscaban reflejar los más mínimos elementos que pudieran tener interés para la interpretación del monumento. Es curioso que se destaque al hablar de él que no fuese buen dibujante, quizás esa limitación le ayudó a depurar su método de levantamiento, arreglándoselas de manera inigualable para conseguir dibujos arquitectónicos que informaban, como nunca se había hecho en nuestro país, las distintas fases constructivas materiales y su datación. Se ha llegado a decir de estos levantamientos que «bastaría añadirles simples numeraciones de las unidades estratigráficas ya allí representadas para convertirlos en documentos de la metodología «Harris» cuyos fundamentos sin duda aplicaba» (Almagro 2013, 355).

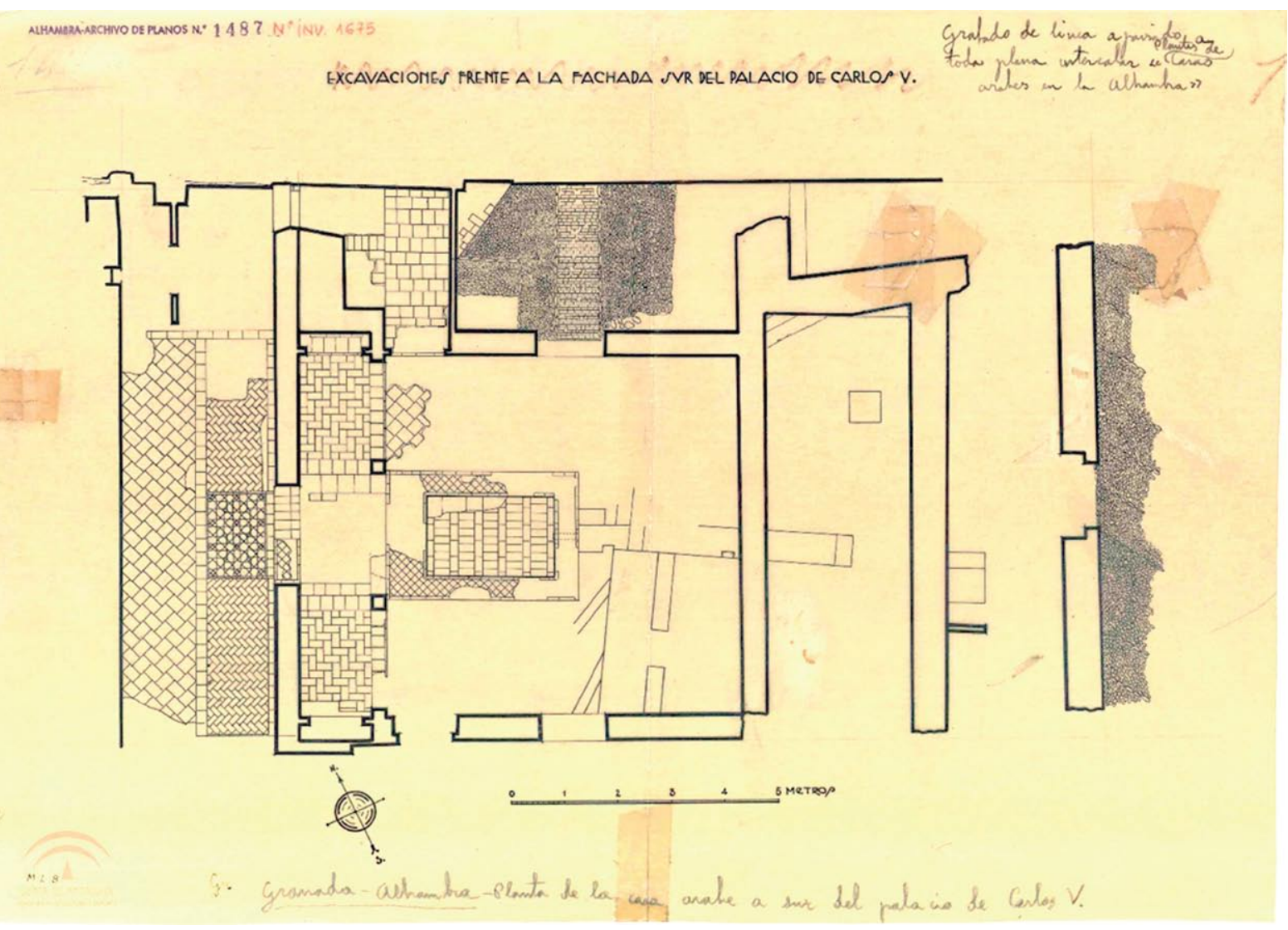

Figura 6. Palacio de Carlos V. Excavaciones frente a la fachada Sur (casas árabes). Leopoldo Torres Balbás. Delineante López Bueno. P. 1675. Archivo Patronato Alhambra y Generalife. 
Su segunda contribución innovadora fue la idea de escribir un Diario de Obras que se asemejaba mucho a un diario de excavación, reflejando cuantas actuaciones, descubrimientos o comentarios surgían en el desarrollo de sus trabajos de restauración. Ello le enseñó con el tiempo a saber reconocer y datar estructuras, incluso donde no había indicadores de restos decorativos, y, comparando las fabricas y solerías de los distintos muros y estancias (figura 6), ir desentrańando la historia y evolución de la Alhambra. Las excavaciones de Torres Balbás no tuvieron por objetivo sacar a la luz estructuras o restos de manera aleatoria, sino clarificar y tratar de ubicar cronológicamente las distintas partes del monumento. Estas prospecciones puntuales las dejaría registradas y documentadas gráficamente al detalle puesto que muchas veces, en el curso de las obras, debía volver a ocultarlas. Los análisis de las fábricas, tanto de sus paramentos como de las técnicas utilizadas, supusieron, en opinión de los arqueólogos actuales, un precedente de la configuración de la disciplina que hoy se denomina como Arqueología de la Arquitectura (Almagro 2013, 354-355).

Podría decirse que Torres Balbás desplegó su actividad en un sentido pionero interdisciplinar, aprovechando cualquier vía de conocimiento, como las transcripciones epigráficas y los documentos escritos, utilizando también, no lo olvidemos, y de ahí lo completo de su resultado interpretativo final, las herramientas metodológicas propias de un historiador del arte. Él no aceptaba en la Alhambra la idea de una totalidad integradora, justo lo contrario de lo que habría defendido un clasicista académico como Hermosilla y, sin embargo, Torres Balbás fue el verdadero artífice de la Alhambra que hoy vemos. La injusta prohibición tras la guerra civil de no poder volver a restaurar, hizo que se refugiase en su cátedra de Historia de la Arquitectura y de las Artes Plásticas de la Escuela de Madrid, que había obtenido por oposición en 1931. Desde esta plataforma, eminentemente pedagógica, alejado de los ámbitos proyectuales arquitectónicos, siguió desarrollando una admirable labor investigadora sobre la historia de la arquitectura española.

\section{Conclusiones}

El progresivo perfeccionamiento de los sistemas gráficos ortogonales y geométricos obedeció a un deseo sobre todo de ciertos arquitectos por captar fielmente la arquitectura del pasado como referentes proyectuales para la renovación arquitectónica que necesitaron en cada momento. Por ello, se puede decir que los arquitectos, desde el principio, cuando dibujaron la arquitectura del pasado, proyectaron sobre ella de alguna manera, aunque fuera de manera inconsciente, y ello se prolongó durante toda la etapa historicista, que iría desde finales del XviII hasta la asimilación del Movimiento Moderno. Aunque los arquitectos fueran incapaces de distanciarse del objeto arquitectónico, sus detallados estudios, aun tendentes a la restitución ideal y a la definición del «monumento-tipo", sirvieron para progresar en el manejo de las herramientas analíticas gráficas de los primeros arqueólogos, dándoles la oportunidad de visualizar gracias a este tipo de dibujo tan analítico los resultados de sus indagaciones sobre los restos del pasado.

Durante la segunda mitad del siglo xix los restos de la Edad Media fueron estudiados por primera vez mediante un sistema comparado formal inspirado en los estudios de los naturalistas, que sirvió para desarrollar el concepto de estilo, fundamental para arrancar con el sistema clasificatorio de los primeros arqueólogos medievalistas, que, por otra parte, todavía se sentían identificados con los historiadores del arte puesto que también utilizaban profusamente los recién creados archivos históricos documentales. Los dibujos técnicos arquitectónicos fueron el soporte y vehículo de esta primera definición e interpretación de la arquitectura medieval que perduraría durante casi todo el siglo $\mathrm{xx}$. 
Por otro lado, el desencuentro entre arquitectos y arqueólogos empezaría a manifestarse cada vez de forma más argumentada y polémica cuando de esos dibujos idealizados se pasó a la intervención física sobre los monumentos reales, es decir, a restaurarlos, y fue palmario el choque sobre todo a partir de las primeras dos décadas del siglo xx. En los arquitectos restauradores primaría durante toda esta larga etapa la recuperación unitaria estilística y «repristinadora» del monumento, aun a costa de destruir la verdadera imagen que nos había llegado a través del tiempo, mientras que los arqueólogos, por reacción, entendieron cada vez más claramente que la materialidad como documento a leer era la única razón de esta salvaguardia. Los dibujos monumentales de los arquitectos fueron muy distintos a partir de entonces. La mayoría se centraron en proyectos de restauración donde expresaron con distintos colores lo original a derruir y lo nuevo a reconstruir, líneas rojas y amarillas que se convirtieron en una constante de estos levantamientos.

Será el arquitecto-historiador Torres Balbás, ya en pleno siglo xx, el que consiga asimilar las primeras aportaciones de la arqueología estratigráfica dando un salto cualitativo en la metodología restauradora, que pondrá de manifiesto la necesidad de integrar interdisciplinarmente la comprensión de la arquitectura histórica. Sus intuiciones y sus experiencias pioneras no se han visto asumidas en nuestro país plenamente hasta la década de los ochenta del siglo xx en la que la fotogrametría y la lectura de paramentos han abierto una nueva etapa que está obligando a redefinir de nuevo la propia arqueología, la restauración arquitectónica y la historia de la arquitectura.

\section{BibLIOGRAFÍA}

Almagro Gorbea, A., 2013, «Estudios islámicos de Torres Balbás», en: Leopoldo Torres Balbás y la restauración científica. Ensayos, Granada: Patronato de la Alhambra y Generalife, Instituto Andaluz del Patrimonio Histórico, 349-359.

Almagro Gorbea, A. (ed. científica), 2015, El legado de al-Ándalus. Las antigüedades árabes en los dibujos de la Academia, Real Academia de Bellas Artes de San Fernando y MAPFRE.

Alonso Martínez, F., 1999, «Recuerdos y Bellezas de España y su relación con el medio fotográfico», $A r$ chivo Español de Arte, 72 (286), 192-198.

Arias Anglés, E., 1986, Jenaro Pérez Villaamil, pintor romántico, Madrid: Consejo Superior de Investigaciones Científicas.

Baldellou, M. Á., 1990, Ricardo Velázquez Bosco, Madrid: Ministerio de Cultura.

Bordes, J., 2014, Monumentos Arquitectónicos de España (1851-1881), Madrid: Real Academia de Bellas Artes de San Fernando, Universidad Politécnica de Madrid, Escuela Técnica Superior de Arquitectura de Madrid.

Caballero Zoreda, L., \& S. Feijoo, 1998, «La iglesia altomedieval de San Juan Bautista de Baños de Cerrato (Palencia)», Archivo Español de Arqueología 71, 181-242.

Calvo Martín, R., 2007-08, «La intervención de la Real Academia de San Fernando en la protección del Patrimonio: la Comisión de Valentín Carderera (1836)», Espacio, Tiempo y Forma, Serie VII. H.a del Arte 20-21, 229-266.

Canto, A., 2001a, «El viaje arquitectónico-anticuario de fray José Ortiz y Sanz: una carta arqueológica de España a fines del XVIII», SPAL 10, 29-55.

Canto, A., 2001b, La arqueología española en la época de Carlos IV y Godoy. Los dibujos de Mérida de Don Manuel de Villena Moziño 1791-1794, Madrid: Fundación El Monte.

Celis D’Amico, F., 1998, La representación gráfica de las ruinas en la segunda mitad del siglo XVIII, Escuela Técnica Superior de Arquitectura de Madrid, Tesis Doctoral inédita.

Celis D’Amico, F., 2006, «Desgodetz y los orígenes del levantamiento moderno», EGA 11, 76-87.

Chony, F., 1992, L'allégorie du patrimoine, Paris: Seuil. 
Gámiz Gordo, A., \& A. J. García Ortega, 2012, «La primera colección de vistas de la Mezquita-Catedral de Córdoba en el Voyage de Laborde (1812)», Archivo Español de Arte 85, 105-124.

García Sánchez, J., 2007, Las pensiones de la Academia de San Fernando en Italia: artistas españoles en el debate arqueológico y arquitectónico en torno a la antigüedad de los siglos XVIII y XIX en Arqueología, coleccionismo y antigüedad: España e Italia en el siglo XIX, Universidad de Sevilla, 193-21.

García SÁnchez, J., 2008, «La Real Academia de San Fernando y la arqueología», Boletín de la Real Academia de San Fernando 106-107, 9-48.

González Reyero, S., 2007, La fotografía en la Arqueología Española (1860-1960). Cien años de discurso arqueológico a través de la imagen, Madrid: Real Academia de la Historia.

Jiménez Martín, A., 2012, "Arquitectura, Dibujo y Arqueología», en: F. Amores Carredano, J. Beltrán Fortes (eds.), Itálica 1912-2012. Centenario de la Declaración como Monumento Nacional, Sevilla: Fundación Itálica de Estudios Clásicos, 213-226.

JimÉnez Martín, A., 2015, «Notas sobre los dibujos de las Antigüedades Árabes y los Monumentos Arquitectónicos», en: El legado de al-Ándalus. Las antigüedades árabes en los dibujos de la Academia, Real Academia de Bellas Artes de San Fernando y MAPFRE, 31-43.

Laborde, A., 1806-1820, Voyage pittoresque et historique de l'Espagne, 4 vols. Paris: Pierre Didot.

Lanzarote Guiral, J. M., 2010, "Apuntes del pasado nacional: aproximación al estudio de los dibujos de monumentos aragoneses de Valentín Carderera», Argensola 120, 141-176.

Luxenberg, A., 2013, Secrets and Glory. Baron Taylor and his Voyage Pittoresque en Espagne, CSA y The Hispanic Society of America.

Maier, J., \& C. Manso (eds.), 2015, Viaje de las Antigüedades de España, 1752-1765: Origen, desarrollo y resultados del viaje arqueológico de Luis José Velázquez; La documentación del Viaje de las Antigüedades de España, Madrid: Real Academia de la Historia.

Madrazo, P. d., 1882, "Elogio fúnebre de D. Valentín Carderera. Necrológica», Boletín de la Real Academia de la Historia II, 5-12, 105-126.

Midant, J.-P., 2001, Au Moyen Âge avec Viollet-le-Duc, Paris: Parangon.

Mora, G., 1998, Historias del mármol. La Arqueología clásica española en el siglo XVIII, Madrid: CSIC.

Ordieres Díez, I., 1995, Historia de la restauración monumental en España (1835-1936), Madrid: Ministerio de Cultura.

Ortega Vidal, J., \& M. Sobrino GonzÁlez, 2007, Estudio preliminar. Monumentos Arquitectónicos de España. Palacio árabe de La Alhambra Madrid, Instituto Juan de Herrera, Escuela Técnica Superior de Arquitectura de Madrid.

Ríos, D. d. 1., 1862, Memoria Arqueológica-descriptiva del Anfiteatro de Itálica, Madrid: Real Academia de la Historia.

Rodríguez Ruiz, D., 1992, La memoria frágil. José Hermosilla y Las Antigüedades Árabes de España, Madrid: Fundación Cultural COAM.

Salas Álvarez, J., \& A. León Gómez, 2003-05, «La representación gráfica de la Antigüedad clásica emeritense durante la Ilustración. El ejemplo del teatro romano. Archaia», en V. Cabrera Valdés, M. Ayarzaguena Sanz (eds.), El nacimiento de la Prehistoria y de la Arqueología Científica, 3-5, 86-103.

Sánchez de León Fernández, A., 1997, «La Academia y la revalorización de los estilos medievales (I). Significado y estudio de los dibujos preparatorios para grabado", Boletín de la Real Academia de Bellas Artes de San Fernando, 85 (2. ${ }^{\circ}$ semestre), 299-343.

Vílchez Vílchez, C., 1988, La Alhambra de Leopoldo Torres Balbás (obras de restauración y conservación. (1923-1936), Granada: Comares.

www (sin año). Carderera, V., 1796-1880, Ávila turismo, consultado en mayo de 2019, http:// muralladeavila.com/es/muralla-artistica/como-la-han-pintado/item/23-carderera-valentín-1796-1880. 